BioLink

JURNAL BIOLOGI LINGKUNGAN, INDUSTRI, KESEHATAN

Available online http://ojs.uma.ac.id/index.php/biolink

\title{
PENGGUNAAN TANAMAN AREN PADA UPACARA SIPAHA LIMA MASYARAKAT PARMALIM
}

\section{The Use of Palm Trees at The Ceremony Sipaha Lima Parmalim Communities}

\author{
Hanifah Mutia Z.N. Amrul* \\ Fakultas Pertanian, Universitas Pembangunan Panca Budi \\ *Corresponding author: E-mail: hanifahmutia@dosen.pancabudi.ac.id
}

\begin{abstract}
Abstrak
Tujuan dari penelitian ini adalah untuk mengetahui manfaat dan lambang yang terkandung pada tanaman aren di upacara Sipaha Lima. Metode yang digunakan dalam penelitian ini adalah metode observasi dan wawancara secara mendalam (depth interview). Data yang diperoleh berupa bagian tumbuhan Aren yang digunakan, cara memperolehnya dan makna tumbuhan tersebut. Hasil penelitian diperoleh delapan jenis kegunaan Aren dalam upacara Sipaha Lima Bagian tumbuhan yang digunakan diantaranya: batang, daun, dan Pelepah. Tumbuhan tersebut diperoleh dari hutan dan pekarangan.
\end{abstract}

Kata kunci: Arenga pinnata, Kegunaan, Upacara

\begin{abstract}
The purpose of this research is to know the beneficiaries and symbols contained in Arenga pinnata in traditional ceremony Sipaha Lima. The method used was the method of observation and depth interview. The data obtained in the form of plant parts used, how to obtain it and the meaning of symbol of the plant. The results is obtained eight types of use of sugar palm in traditional ceremony Sipaha Lima. Part of the plants used are: stems, leaves, and midrib. The plant was obtained from forests and house yard.

Keywords: Arenga pinnata, Usability, Ceremony
\end{abstract}

How to Cite: Amrul, Hanifah M.Z.N, 2018, Penggunaan Tanaman Aren pada Upacara Sipaha Lima Masyarakat Parmalim, BioLink, Vol. 4 (2): Hal. 


\section{PENDAHULUAN}

Tanaman aren dikenal dengan nama botani Arenga pinnata Merr. Tanaman aren bisa dijumpai dari pantai barat India sampai ke sebelah selatan Cina dan juga kepulauan Guam. Habitat aren juga banyak terdapat di Philipina, Malaysia, dataran Assam di India, Laos, Kamboja, Vietnam, Birma (Myanmar), Srilanka dan Thailand (Lutony, 1993).

Aren (Arenga pinnata Merr.) adalah salah satu species yang termasuk dalam famili Arecaceae. Banyak nama daerah (Vernacular names) yang diberikan untuk aren di Indonesia, hal ini karena tingkat penyebarannya sangat luas. Nama-nama daerah tanaman aren di Indonesia (Lutony, 1993) antara lain: bak juk (Aceh), paula (Karo), bagot (Toba), bargot (Mandailing), anau, biluluak (Minangkabau), kawung, taren (Sunda), aren, lirang (Jawa, Madura), jaka, hano (Bali), pola (Sumbawa), nao (Bima), kolotu (Sumba), moke (Flores), seho (Manado), saguer (Minahasa), segeru (Maluku), ngkonau (Kaili).

Parmalim adalah sebuah agama yang dikenal dengan ugamo malim. Malim adalah agama asli yang dianut Bangsa Batak sebelum agama Islam, Kristen dan Katolik. Penganut Ugamo Malim disebut Parmalim, pimpinan tertinggi Ugamo Malim adalah Raja Sisingamangaraja I-XII. Saat ini Parmalim yang tersisa di Tanah Batak hanya sekitar 10.000 orang. Ugamo Malim terpusat di Huta Tinggi, Laguboti Kabupaten Tobasa. Pimpinan Parmalim bernama Raja Marnangkok Naipospos, meneruskan kepemimpinan Raja Sisingamangaraja Sinambela XII (Anonim, 2007).
Dalam kehidupan sehari-hari Parmalim memiliki beberapa upacara adat seperti Sipaha Sipaha Lima, disetiap upara adat tersebut digunakan berbagai jenis tumbuhan sebagai makanan, sesajian dan juga sebagai hiasan. Terkait dengan hal tersebut, pemanfaatan berbagai jenis tumbuhan serta sumber tanaman tersebut belum diketahui. Menurut Tamin dan Arbain (1995) dalam suswita et. al., (2013) menyatakan bahwa untuk mendapatkan informasi tentang pemanfaatan tumbuhan oleh suatu masyarakat tradisional suku bangsa dilakukan dengan studi etnobotani.

Berdasarkan hal tersebut, penulis ingin melakukan penelitian tentang penggunaan aren dalam upacara Sipaha Lima Masyarakat Parmalim. Hasil dari penelitian ini diharapkan dapat sebagai sumber informasi tentang berbagai kegunaan aren.

\section{METODE PENELITIAN}

Metode penelitian dilakukan dengan metode observasi dan wawancara secara mendalam (depth interview). Wawancara ditujukan kepada ketua adat, lembaga adat dan masyarakat pengguna atau mengenal tentang pemanfaatan tumbuhan aren dalam upacara adat, dengan metode pengambilan sampel secara purposive sampling (Singarimbun dan Effendi, 1995).

Cara memperole daun aren diperoleh dari ladang atau kebun yang berada disekitar masyarakat Parmalim.

\section{Analisis data}

Metode yang digunakan dalam analisis data adalah analisis deskriptif. Data yang dianalisis berupa jenis-jenis tumbuhan yang digunakan, 
pemanfaatannya, cara mendapatkan tumbuhan tersebut (tanaman budidaya atau tanaman hutan).

\section{HASIL DAN PEMBAHASAN}

Bagian tumbuhan aren yang digunakan adalah daun dan pelepah daun. Daun yang digunakan daun muda dan daun tua.

Tanaman Aren yang dimanfaatkan oleh masyarakat khususnya masyarakat Parmalim masih merupakan tanaman aren yang tumbuh dengan sendirinya, dan bukan merupakan tanaman budidaya. Hal serupa juga diunggkapkan oleh Effendy et. al., (2013), dimana Aren (Arenga pinnata Merr.) adalah salah satu tanaman yang mempunyai banyak manfaat seperti buahnya yang diambil untuk bahan makananmaupun

minuman, selain itu juga dapat menghasilkan nira, selain itu juga proses lanjutan dari pengambilan air nira dapat diolah menjadi bahan pemanis. Tanaman Aren yang dijadikan sebagai bahan baku pemanis di Kalimantan Selatan, khususnya kabupaten Hulu Sungai Selatan sampai saat ini masih berasal dari tanaman alam yang tumbuh pada habitatnya.

Pengamatan langsung terhadap Upacara Sipaha Lima dan hasil wawancara terhadap Ihuta dan Ulu Punguan Parmalim, diperoleh beberapa jenis penggunaan Aren, yaitu:

Tabel 1. Beberapa kegunaan tanaman aren pada upacara Sipaha Lima Masyarakat Parmalim

\begin{tabular}{|c|c|c|}
\hline No & Kegunaan/Fungsi & $\begin{array}{l}\text { Bagian Tumbuhan yang } \\
\text { Dimanfaatkan }\end{array}$ \\
\hline 1 & $\begin{array}{l}\text { Sebagai Tiang untuk mengikatkan Bendera. } \\
\text { Bendera ini melambangkan tentang Ugamo } \\
\text { Malim. }\end{array}$ & $\begin{array}{l}\text { pelepah Aren dan sedikit } \\
\text { daun yang sudah tua. }\end{array}$ \\
\hline 2 & $\begin{array}{l}\text { Sebagai hiasan pada tempat untuk } \\
\text { meletakkan Persembahan kepada Sang } \\
\text { Pencipta (Mulajadi Nabolon). }\end{array}$ & $\begin{array}{l}\text { daun aren yang masih muda } \\
\text { atau berwarna kuning ke } \\
\text { hijauan. }\end{array}$ \\
\hline 3 & $\begin{array}{l}\text { Sebagai tempat pengikat (penambat) Kerbau } \\
\text { dan hiasan ekor kerbau. }\end{array}$ & $\begin{array}{l}\text { daun muda dari tanaman } \\
\text { aren yang berwarna kuning } \\
\text { kehijauan. }\end{array}$ \\
\hline 4 & Burung yang diikatkan pada ranting pohon & $\begin{array}{l}\text { daun aren yang masih } \\
\text { muda, kenudian di buat } \\
\text { seperti burung yang sedang } \\
\text { terbang. Filosofi yang } \\
\text { terkandung disini adalah, } \\
\text { pada awalnya ketika anak- } \\
\text { anak menanyakan melalui }\end{array}$ \\
\hline
\end{tabular}




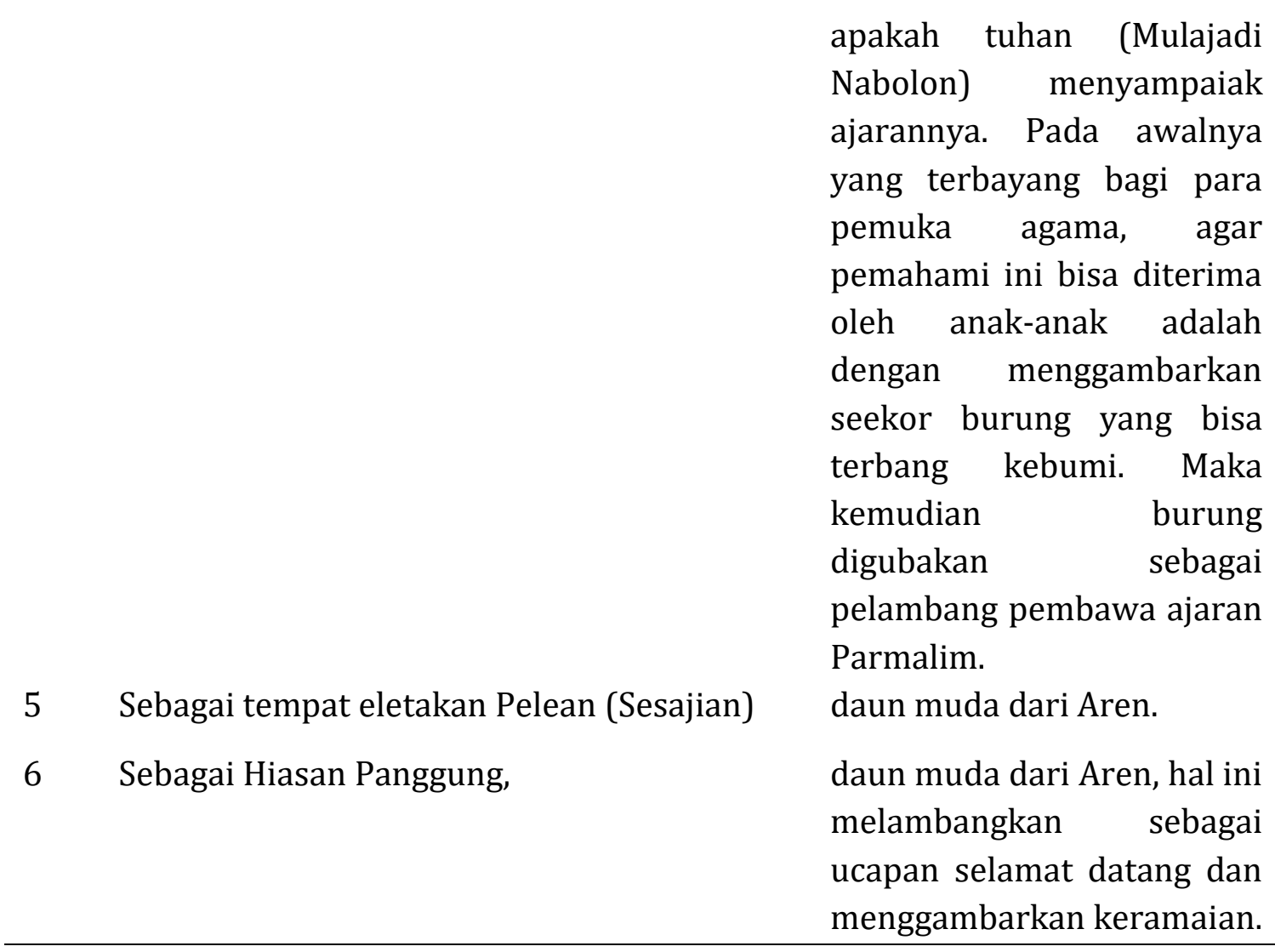

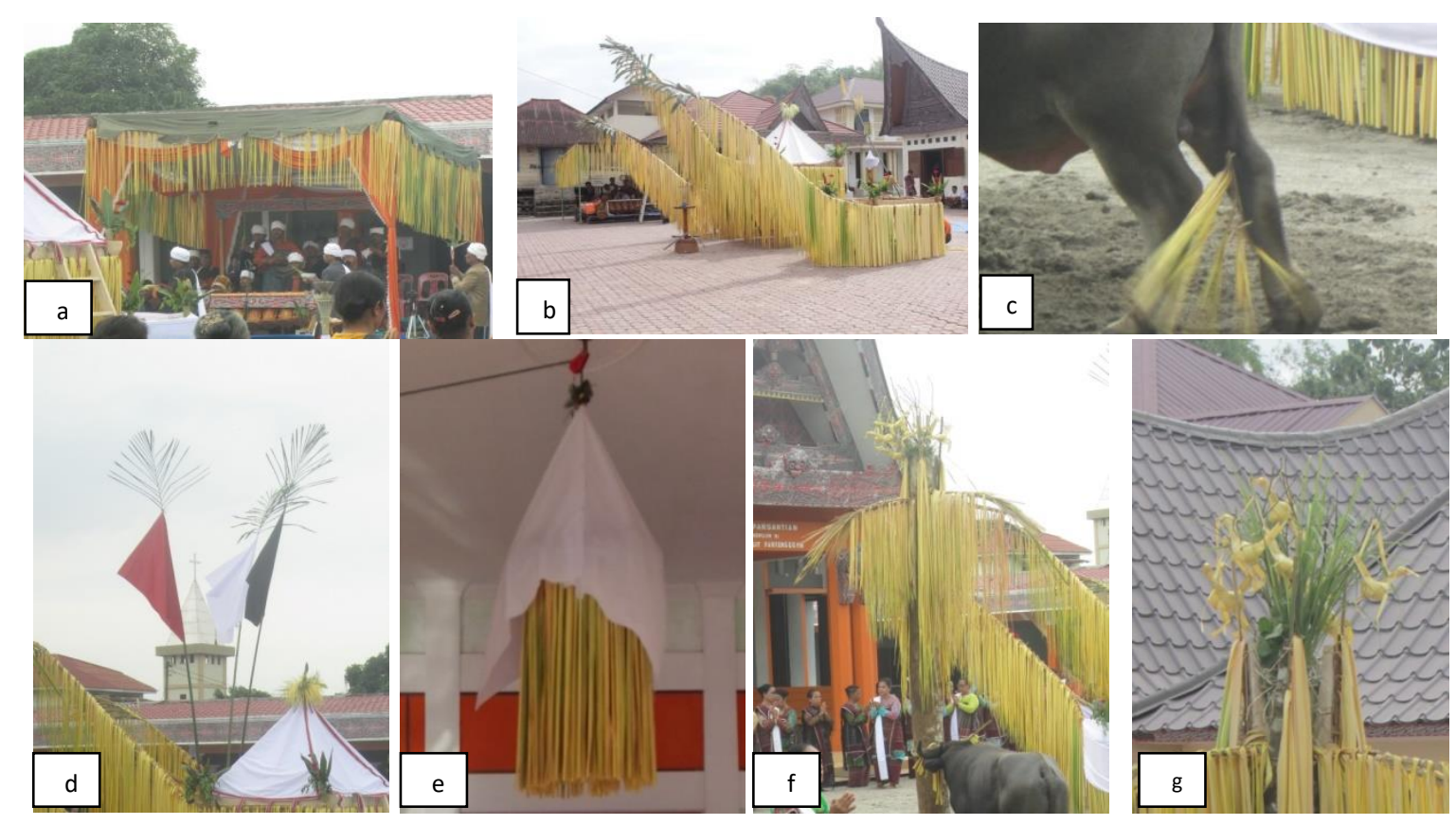

Gambar 1. Beberapa bentuk penggunaan tanaman aren pada upacara Sipaha Lima Keterangan : $a$ dan $b=$ aren digunakan sebagai lambang keramaian; $c=$ aren sebagai hiasan ekor kerbau; $d=$ pelepah aren sebagai tiang bendera; $\mathrm{e}=$ aren pada tempat sesajian; $\mathrm{f}$ dan $\mathrm{g}=$ aren sebagai pelambang pada tiang pengikat kerbau 
Menurut Lempang (2012), aren merupakan pohon yang hampir semua bagian tumbuhan dapat dimanfaatkan dan memilki nilai ekonomi. Produksi aren seperti buah, nira dan tepung sudah dimanfaatkan sejak lama. Saat ini yang masih perlu pengembangan lebih lanjut adalah pemanfaatan nira aren untuk cuka, etanol dan nata.

\section{SIMPULAN}

Hasil penelitian diperoleh delapan jenis kegunaan Aren dalam upacara Sipaha Lima. Bagian tumbuhan yang digunakan diantaranya: batang, daun, dan Pelepah.

\section{DAFTAR PUSTAKA}

Anonim, 2013. Pedoman Budidaya Aren (Arenga pinnata MERR) Yang Baik. Peraturan Menteri Pertanian Republik Indonesia Nomor 133/Permentan/OT.140/12/20134.12011 Tentang Pedoman Budidaya Aren (Arenga pinnata MERR) Yang Baik. http://ditjenpp.kemenkumham.go.id/ arsip/bn/2014/bn17-2014lamp.pdf. Diunggah pada tanggal 1 September 2017. Effendy M, Dina Naemah. Winarni Emmy dan Fitriani Adistina. 2013. Studi Potensi Tanman Aren di Desa Batang Kulur, Kandangan Kabupaten Hulu Sungai Selatan. Laporan Penelitian. Fakultas Kehutanan Universitas Lambung Mangkurat Banjar Baru.

Lempang Mody. 2012. Pohon Aren dan Manfaat Produksinya. Info Teknis Eboni. Volume 9 Nomor 1 Oktober 2012. P: 37-54

Lutony.1993. Tanaman Sumber Pemanis. Surabaya : Penebar Swadaya

Ramadani P., I. Khaeruddin, A. Tjoa dan I.F. Burhanuddin. 2008. Pengenalan JenisJenis Pohon Yang Umum di Sulawesi. UNTAD Press, Palu.

Soeseno, S., 1991. Bertanam Aren. P.T. Penebar Swadaya, Jakarta.

Singarimbun dan Effendi. 1995. Metode Penelitian Survai. Jakarta: PT. Pustaka $\mathrm{LP}_{3} \mathrm{ES}$. Yogyakarta.

Steenis, CGGJ van. 2013. Flora, untuk sekolah di Indonesia. PT Balai Pustaka, Jakarta.

Suswita D, Syamsuardi dan Ardinis Arbain, 2013. Studi Etnobotani dan Bentuk Upaya pelestarian tumbuhan yang digunakan dalam upacara adat kendurisko di beberapa kecamatan di Kabupaten Kerinci Jambi.Jurnal Biologika. Vol 2, No 1 Tahun 2013. Hal. 67-8o 